\title{
Independent English Learning through the Internet
}

\author{
Mohammad Nurul Islam \\ Department of English, Faculty of Languages \& Translation, King Khalid University, Kingdom of Saudi Arabia \\ Email:nurulelt313@yahoo.com
}

\begin{abstract}
The studies on independent learning based on the theories of constructivism and the advantages of technology propose valuable ideas for modern teaching theories and practices. With the variety of environment and method of English learning, independent English Learning through the Internet is playing a more and more important role in modern English learning. It challenges the traditional learning approach, and also is forwardness. This paper points out that independent English Learning through the Internet facilitates the improvement of the English level even more on the basis of the author's acquisition and experience, as well as explains the favorable factors and unfavorable factors of autonomy English learning on the Internet, suggesting the effective strategies of independent English learning through the Internet.
\end{abstract}

Index Terms - constructivism, independent English learning, Internet, virtual English environment.

\section{INTRODUCTION}

Nowadays, quality-oriented education has become the ultimate goal of our education. The core of English learning has shifted to how to develop the ability of autonomy learning anytime and anywhere. The application of internet technology has developed a new field for autonomy English learning which is becoming more and more popular at home and abroad. Learning English on the Internet can create efficient and high-quality achievement in personal or mass English learning. More and more people start to pay attention to it and study how to make a full use of it. English learning needs an English environment, but we cannot always communicate with the native speakers of English face to face. What teaching of traditional English adopted is one-way teaching mode from teacher to student, which violates the essence of language teaching that is cultivating students' language communication competence. Now, we could say that the Internet shrinks and bridges the distance between the people of the world in space, and makes a globalized communicational stage. The way using the Internet to learn English can compensate for the lack of general approach with no real English environment, which will greatly enhance English autonomy learning.

Autonomous -Learning is a modern learning theory of constructivism which means the students take charge of their own learning by caring out their own learning plans according to their own needs. It is also a student-focused learning model which emphasizes the learning environment and cooperative learning. In 1981, Holec Henry introduced the concept of "autonomous learning" in his book named Autonomy and Foreign language learning. After that, many scholars such as Lee (1998), Littlewood (2000), Garden and Miller(2002) studied the issue and made greater contribution to the field.

By computer-aided autonomous English learning, we mean students learn and practice English language not only in the classrooms but also computer-rooms using materials on internet, learning discs and other electronic learning tools.

However, in Asia, The efficiency of the use of Internet to autonomy English learning is low, the result is not satisfactory. What are the reasons and how to deal well with the permanent approach for the ideal goal of autonomy English learning is a must to seek for the resolution.

\section{USING THE INTERNET AND TECHNOLOGY}

With the use of the Internet and computers increasing around the world, it seems obvious that electronic means will provide the learning environment of the future. Instant messaging has been quite popular for some time and the rate of usage around the world is increasing as more people, especially in developing countries, are able to get online. Other forms of communication over the Internet include discussion boards, interactive blogs, and online forums. In addition, many English students are downloading English music, movies, and TV shows that allow them to get exposure to different accents and expressions from around the world. Other virtual environments can be used to develop language skills while also morphing the task of learning into an enjoyable hobby. Social networks such as Face book, MySpace and Second Life have the potential to create awareness about language that will drive people at a very young age to become involved in learning language.

Second Life, is a free program from the internet that allows you to create your own virtual environment where you can interact in real time through talking or typing with over 12 million subscribers worldwide. This environment, where you create a name and an avatar for yourself, enables the user to create a world where they are surrounded by stimulus 
that interests them and where they can easily meet others with common interests and characteristics. While controlling your character in this world, you can go to parks, shops, and even your own living room with a group of friends. Now with the capability to use voice chat in Second Life, it is possible to use this as an effective tool for learning language. Without the pressure of having to introduce themselves in a real classroom with other students, Second Life provides an unintimidating environment where students can introduce their virtual characters and acquire information from other characters. Facebook and MySpace can help a learner present themselves and learn more about others, but unlike Second Life, they are not presented in a 3D environment and cannot be used to speak with others.

Other technological means that can be used to improve language ability are voice-chat programs such as Skype, iChat, and messenger programs such as MSN and Yahoo. These voice-chat programs allow people to talk to others around the world in real time and they are free to use. When initial connections are made through social networks on the Internet, users can then use these voice programs to call each other and practice oral skills by applying new language items learned through writing and reading. To fully take advantage of the Internet during the learning process, one should consider other on-line programs and functions such as relative readings, blogs, online quizzes, and podcasts. While many students and professionals around the world have lengthy commutes to and from school or work, downloading podcasts onto a listening device makes exposure to spoken English possible on a train, bus, or even while stuck in rush-hour traffic.

\section{THE BENEFITS OF INDEPENDENT LEARNING}

For EFL/ESL students who are more introverted and concerned about privacy issues, the use of virtual worlds to encourage learning is an attractive option. Instead of sharing personal information with strangers, the learner can instead share information about their virtual character that they have created based on their fantasy and interests. This would be a great way to build both confidence and networking skills with a foreign language. Again, the merits of this approach rely on the studying goals of the learner. For example, this most likely would not improve English skills for specific purposes, such as business situations.

Especially in large EFL classrooms, there are proactive students who are motivated to learn both independently and as a group. However, others are satisfied simply with the limited exposure that they get from the class and some of these students choose not to focus during the lessons. In a 1995 research project on learner agendas, it was suggested that "while the teacher is busily teaching one thing, the learner is often focused on something else"(Nunan, 2000). It can be argued that this is amplified in Asia, where students are sometimes expected to spend twelve hours a day studying for tests or working in the office while at times juggling other responsibilities such as a family.

\section{CHARACTERISTICS OF THE SUCCESSFUL INDEPENDENT LEARNER}

In David Nunan's (2000) study, he outlines common characteristics for people who successfully and dramatically improved their language skills through learning autonomously. These characteristics and requirements include: a diversity of skills, passion and enjoyment for a particular field, a focused and active approach to learning, and finally, pursuit of learning and success despite high probability of failure and public disapproval. While most learners in Japan are wary about taking these risks, there are many examples of those who do with favorable results. Nunan (2000) presents a couple success stories in Hong Kong of students who took their learning in their own hands and excelled because of it.

One student named 'Josephine' once approached Nunan to inform him of the great progress she was making with her English. When Nunan continued to give himself as the teacher credit for the improvements, Josephine countered that it was not his lesson that resulted in her improvements, but her domestic situation living with a Canadian roommate. (Nunan, 2000) In a second example, Nunan (2000) describes the language development of another student by the name of 'Siu Fun': “she loved English but she quickly came to realize that learning English in school wasn't enough so she found opportunities to practice her English out of class... Siu Fun used to hang around the tourist traps after school (to interact with foreigners in English)". (Nunan, 2000) Similar examples can be found in Japan, where students who are very keen to learn English will volunteer at tourist venues (museums, shrines, and temples) in need of an interpreter. What these learners have in common is that their attitudes were developed after they made a decision for themselves that exclusively studying in a classroom environment was not enough. While it is difficult to implant this attitude in other language students' psyche, the first step for the instructor to encourage this is to better understand the attitudes and needs of the student.

\section{THE ROLE OF INSTRUCTOR IN INDEPENDENT LEARNING}

While examples of several exceptional students have been given, the fact remains that the average student does not possess the drive or motivation to acquire language this way. In their 2002 study, Chen, Spratt, and Humphreys conducted a large-scale study on learner autonomy at the Hong Kong Polytechnic University where they aimed to represent the students' views on responsibility, motivation, and decision making outside of the classroom. In this study, Chen et al. conclude that the vast majority of students view their instructor as playing a major role in the development of their language skills. This study has pedagogical implications, as it is argues that understanding the students' 
perceptions on learning can help a teacher identify what responsibilities can be transferred to the student. (Chen et al., 2002)

This is quite similar to the case in Japan, where a lot of pressure is placed on students to succeed which in turn discourages one from taking learning into their own hands. It appears safer for the student to follow the lead of the instructor. While language learners in Asia are exposed to studying language at a very young age as a means to pass an entrance test, this has really resulted in a spoon-feeding education system where the student needs to focus on the material presented in class in order to pass a test that will ultimately determine the university they attend and the career options that may be presented to them after graduation.

\section{FAVORABLE FACTORS OF INDEPENDENT ENGLISH LEARNING THROUGH THE INTERNET}

Independent English learning on the Internet is one of the most important learning approaches which mostly reflects the main part and individual-orientation of students' study. According to one's conditions, a person can choose the learning materials, methods and the depth of study; arrange study on one's own schedule. As we all know, different people have different background knowledge, study ability and cognitive ability on study. In class, teachers always have no time to focus on the different acceptance specially. So, there is not efficient. While it is extremely different in the approach of autonomy English learning on the Internet, which always offers the great initiative on study, rich variety of choices, typical individual character of study, notional flexibility for arrangement and pleased dynamic interaction. Of course, there are some relatively unfavorable factors of autonomy English learning on the Internet, for example, appearing poor ability of learner's autonomy English learning, negative impact of English learning motivation and other external environmental impact. It is a considerable issue to find the resolution to overcoming how to approach the former and avoid the latter. All in all, autonomy English learning on the Internet depends on the learners' internal factors. Adding to teachers' supervision, assistance and guidance, the subjective willing of the learners is the key to the goal of learning English on the Internet well.

\section{REQUIREMENTS FOR EFFICIENCY OF INDEPENDENT ENGLISH LEARNING THROUGH THE INTERNET}

\section{A. Promoting Self- monitoring Ability}

Self-monitoring ability is to play full the enthusiasm of learners and the initiative of learning, and gives the main body of individual the fundamental recognition. The self-monitoring level of students is the key factor to success in autonomy English learning in the relatively free-loose Internet environment. The Cognitive Constructivism School believed that autonomy learning was actually the learning of cognitive monitoring, and the process those students actively adjust learning strategies and effort based on their learning abilities and learning tasks. Learning strategies mean the various actions and steps students take in order to effectively study and develop themselves. In order to really realize promoting self-monitoring ability, the followings are additional. First, learners should establish a good learning goal. Second, learners should formulate feasible study plan. Third, learners should optimize the self-evaluation for his learning process, confidence and effects.

\section{B. Strengthening Cooperation}

In the situation of all mass organizations, random and disorder, which easily lead to "information Trek" and "information overload", and at the isolation between students and teachers, which always leads the role of teacher and teaching management weakening at learning on the Internet, it is very practical for the present learners to strengthen and develop the strong awareness of cooperation among the mass of autonomy English learners on the Internet. Most students in the personal autonomy English learning on the Internet are generally lack of stamina. The development of autonomy English learning ability on the Internet should not be blindly optimistic. First all, they need realize that fact that teachers are the most direct and important guide, partners and supervisors for providing a good environment, helping students strengthen their autonomy consciousness and develop independent learning behaviors, so as to enhance the capacity of autonomy learning, specifically to manifest in learning strategies, to ensure the implementation of the plan, to build a learning platform for students and timely to provide students with the necessary knowledge, skills and many other help; to direct students formulate learning goals, to encourage more cooperation between the learner groups and supervise the realization of self-evaluation

\section{Optimizing of Network Configuration}

There are many elements to influence the quality of English learning network, such as, the restriction of builders' purpose, foreign languages level, technology. As well as, the laws and regulations to protect the copyright of network is imperfect at present. The contents of the website are seriously challenged. We should establish a sense of innovation and appeal to professionals joining in the building of websites for the stabile team of building sites. Sites builders' occupation, education philosophy, English degree, the level of modern educational technology, and interest can influence the quality of websites. Voices of English as an example: because site builders are experts of foreign language teaching and network education, its website has these advantages: positioning clear, distinctive features, abundant resources, rational design and high interactive. Excellent English language learning websites should reflect the 
advanced teaching philosophy. The development of English-language websites ultimately depends on English educators of their own efforts.

English teachers are familiar with the teaching and learning process and education regulation that should become the major force of the construction of sites. Measures should be taken to guide and encourage English teachers learning multimedia and network technology, and actively participate in the construction of English learning websites, so that they can establish a number of high-quality sites to meet the growing demands of English learners and promote network process of China's English Learning. At the same time, we should encourage dialogues between English teachers and computer or network professional and technical personnel to cooperate in the development of sites, in order to form a specialized and diversified construction site team for the whole soul and heart to serve the learner on Internet.

\section{APPROACHES OF INDEPENDENT ENGLISH LEARNING THROUGH THE INTERNET}

\section{A. English Learning Website}

As we all know, the content and knowledge in class are limited, and are impractical. The application of Internet technology has greatly broken the limitations of space and time in class. Autonomy English learning on the Internet can spread the knowledge from in class to out of class. Of course, websites cannot take the place of library, but it has its own special functions while the library has not, such as, speed of search, immediate information, etc. Some sites provide large amount of English language learning and information, such as listening, speaking, reading, writing, grammar, testing, and background knowledge. That information, including some audio and visual information can be downloaded. It has been recommended two foreign English language learning websites as following:

1) http://eleaston.com/english.html

2) http://www.eslcafe.com/

If you want to visit more pages, you can use the search engine, such as: Yahoo. You can type: "TESL", "ESL", "TEFL", "EFL", "English learning"," English Study", or "Distance learning", you will get what you want.

\section{B. EX*CHANGE: An ESL Web Magazine}

In an initial attempt to implement language learning resources on the $\mathrm{Web}, \mathrm{Li}$ and other graduate students at University of Illinois at Urbana-Champaign founded the ESL web magazine EX*CHANGE(Shetzer, 1995; Zhao, Li \& Hegelheimer, 1995). Their purpose was to explore ways in which high-quality ESL learning resources could be accumulated, organized and presented on the Web.

\section{English Learning Discussion Group by E-mail}

It's a more economic way to subscribe by e-mail. There are many English learning discussion groups on the Internet, such as, the intensive English forum, science and technology English forum, the English Writing forum and teaching discussion forum. I recommend three abroad discussion groups. 1) "English writing forum": you should send an email to the address: listerv@listserv.net. You should write "SUBSCRIBE ECOMP-L" on letter body. 2) "English learning lover": you should send an email to the address: Majordomo@coe.Missouri.edu. Besides, you should write "subscribe English-L" on letter body. 3) "BBC": you should send an email to the address: Majordomo@listserv.bbc.uk and you should write "subscribe BBC-ELT" on letter body.

There are different methods to subscribe to the different thematic discussion groups. Generally speaking, when one sends these e-mails to reserve some topics of discussion groups, will receive two letters. One is that you have been notified to accede to the forum; the other is to introduce something about it, such as the aims, using method, managers and competent units of the name and address. Some enable you to reply upon its requirements, and some let you read the group's charter and regulations. After agreement, you have to reply a signed e-mail to two important addresses. One is sent to all members of topics discussion group, where you can ask questions or raise your points of view on the issues of others. If the group includes 1,000 people, all of them can see your issues and perspectives. The other is sent to the person in charge of the group. If you have any technical problems or you want to withdraw from this group, you can send an e-mail to this address with much care.

\section{English Chat Room}

In order to develop oral English, many people take oral class, chat with foreign teachers, or participate in English corners on campus. However, they still find it little effective. The key reason is that their confidence is not enough. And the next is their package of abundant practice.

Now, you can invite foreign teachers to your home and talk with native speakers anywhere and anytime. That makes the best use of the communication function of the Internet and brakes limitation of time and space. English chatting needs quick reflection. So, it's a very good promotion to virtual communication. Chatting on the Internet, you can understand different country's cultural connotation and background. Meanwhile, it can stimulate the interest in oral or write, and improve the level step by step.

\section{E. Foreign Pen Pals on Internet}


We can communicate with foreign pen pals via e-mail on the Internet. There are several websites to making pen pals. In these pages, you can see the dating ads by people from various countries to make friends. You can choose to make your friends, or you could play your own Personal ads, soon you will receive the e-mail from your friends. I recommend three pen pal web sites:

(1).http://www.wfi.fr/volterre/keypals.html

(2). http://deil2.lang.uiuc.edu/penpals/

(3) http://www.linguistic-funland.com/addapal.html

If you want to visit more friends' websites, you can search them through engines. You can type "pen pal" and "key pal", you will find more websites.

\section{F. Online Electronic Bulletin Board System}

Electronic bulletin boards system (BBS) also is called 'forum'. We can participate in online electronic bulletin board system to English study and discussion. Electronic bulletin boards system like a big bulletin board, you can paste the issue of English learning to the above, and advocate the problems in the process of learning English. You can exchange of experience and discuss with your friends to find the best answer on it. Firstly, you have to conduct user registration in the relevant forums, such as the English forums of Sohu educational channel (http://learning.sohu.com/), and then enter into the bulletin board. If you want to visit more electronic bulletin board system, you can type "BBS" to conduct searches.

\section{G. About Computer-room Learning Materials}

Some ESL teachers in China (2010) carefully reviewed and previewed software; they want learners to use to ensure an appropriate fit with their lesson objectives.

H. The Web-sites Teacher Chose for Students Were:

(1)About computer knowledge and skills: www.ask.com/, www.ajkids.com/, www.encarta.msn.com/, www.google.com, www.about.com/, and www.demoz.org/.

(2)About English language: http://languagetrade.com, http://how-tolearn-any-language.com/e/index.html, www.yeword.net/, http;//www.mylanguageexchange.com/, www.learningenglish.org.uk/, www.chompchomp.com/, www.hua.umf.maine.edu/, www.chinatoday.com/, www.index-china.com/, www.chaos.umd.edu/, and www.artbin.com/, www.chinavista.com/

(3)About culture: http://69.93.14.237/index.cfm, http://spankmag.com/(worldwide site focusing on youth issues).

(4)About dictionary: www.dictionaries.com/, www.rootsweb.com

\section{An Amazing Tool to Explore EFL/ESL Learners' Words: Thanks Microsoft}

Click the following link, download, install and see the magic of word:

http://download.cnet.com/WordWeb/3000-2279_4-10003201.html?part=dl-WordWeb\&subj=dl\&tag=button

WordWeb is an international English dictionary and thesaurus program for Microsoft Windows and iPhone. Available for download online, the program is partly based on the WordNet database.

The program is activated by holding down CTRL and right-clicking on a word in almost any program. This opens the WordWeb main window, with definitions and other help.

The program usually resides in the tray, and has a low system footprint.

- Phrase guessing - for example, CTRL + right-clicking on the 'Princeton' in 'Princeton University' will show the meaning of the combined entity rather than only 'Princeton'.

- Words from pictures - CTRL + right-clicking on a word within an image (for example, the 'Free' in the Wikipedia logo) will ask WordWeb to guess the word. (Note that right-clicking 'Encyclopedia' in the same logo returns 'Emyrlnpewa').

WordWeb 5 added the ability to list entries from three web sources: Wikipedia, Wiktionary, and WordWeb Online. These details are presented in three separate tabs, which are built into the client application. Version 6 added audio pronunciations and support for third-party Oxford and Chambers add-on dictionaries.

\section{CONCLUSION}

A paper of this length cannot completely cover the topic of internet-based language learning. In the end, it has been uncovered that the approach of independent English learning through the Internet is completely different from the traditional one. Learners obtain knowledge on the Internet instead of lonely dependence on teachers and books. Learning resources from the Internet not only are very colorful, but also multi-channeled, multi-perspective, multileveled and multi-formed. In addition, it is very quick and timely. We can choose learning materials from the extensive resources we need on the Internet, thus which easily aroused keen interest in learning initiative. It can fully move the initiative and enthusiasm and improve the learning efficiency. Although independent learning on the Internet can bring so much benefit and convenience to us, it's no enough to be used. If we really make the best use of it, our English learning will be expected and successful. Independent English learning through the Internet will be popular with everybody fully in the future. Moreover, in attempts to promote a higher level of learner autonomy in Asia, it is 
important for the instructor to encourage and organize team activities and homework assignments that will force students to explore realms and means that could ultimately pique a greater interest in autonomous learning. As English instructors, it becomes our responsibility to not only teach a language, but to also inform and instruct how to study outside the classroom. This will be accomplished by presenting tasks that inspire the learner to take learning into their own hands. Everyone will develop and strengthen the ability of Independent English learning through the Internet, so that we can acquire the skill of life-long learning to serve ourselves and the whole society better.

\section{REFERENCES}

[1] Chan, V. Spratt, M. and Humphreys, G. (2002). Autonomous Language Learning: Hong Kong Tertiary Students' Attitudes and Behaviours. Journal of Evaluation and Research in Education, Vol.16, No.1. Retrieved April 29th, 2008 from http://www.multilingual-matters.net/erie/016/0001/erie0160001.pdf

[2] Chanock, K. (2004). Autonomy and Responsibility: Same or Different? Retrieved April 29th, 2008 from http://independentlearning.org/ILA/ila03/ila03_chanock.pdf?q=ila03/ila03_chanock.pdf

[3] Conttia, L.M.W. (2007). The Influence of Learner Motivation on Developing Autonomous Learning in an English-for-SpecificPurposes Course. Retrieved April 29th, 2008 from_http://www.asian-efl- journal.com/thesis_lai_conttia.pdf

[4] Donahue, R.T. (2002). Guideposts for Exploring Japaneseness. Exploring Japaneseness: On Japanese Enactments of Culture and Consciousness. CT, USA: Greenwood Publishing. pp. 3-27

[5] Fanany, R. (2005). Autonomous Learning Through Online Teaching. PacCALL Journal, Vol.1, No.1, pp25-52. Retrieved April 29th 2008 from http://paccall.org/Journal/V-1-1-papers/Fanany-Autonomous-Learning- Online.pdf

[6] Gardner D. \& Miller L. (2002). Establishing Self-access: From theory to practice. Shanghai: Shanghai Foreign Language Education Press.

[7] Holec, H.(1981). Autonomy and foreign language learning, Oxford: Pergamon Oress.

[8] Jarvis, H. (2005).Technology and Change in English Language Teaching (ELT), Asian EFL Journal, December 2005, Volume 7, Issue 4, Article 13. Retrieved April 1st from http://www.asian-efl- journal.com/December_05_hj.php

[9] Knowles, M.S. (1980). The Modern Practice of Adult Education; From Andragogy to Pedagogy. Englewood http://www.asianefl-journal.com/December_05_hj.phpCliffs, NJ: Cambridge Adult Education.

[10] Lee, I. (1998). Supporting greater autonomy in language learning. ELT Journal, 52(4), 282-291.

[11] Littlewood, W. (2000). Do Asian students really want to listen and obey? ELT Journal, 54 (1), 31-36.

[12] Nowlan ,Andrew G. P. (2008) Motivation and Learner Autonomy: Activities to Encourage Independent Study. The Internet TESL Journal, Vol. XIV, No. 10, October 2008. http://iteslj.org/

[13] Nunan, D. (2000). Autonomy in Language Learning. Retrieved April 29th, 2008 from http://www.nunan.info/presentations/autonomy_lang_learn.pdf

[14] Opalka, B. (2001). Reflective Learning in the Autonomous Classroom. Retrieved April 29th, 2008 from http://www.iatefl.org.pl/tdal/n9reflective.htm

[15] Ozmen, K.S. (2004). Make them be Aware, not Beware of Learning, Asian EFL Journal, Volume 6. (Issue 1 Article 6)

[16] Rendon, M.J. (1995). Learner Autonomy and Cooperative Learning. English Teaching Forum, Vol. 33, No.4, p.41. Retrieved April 29th, 2008 from http://exchanges.state.gov/forum/vols/vol33/no4/p41.htm

[17] Shetzer, H. (1995). EX*CHANGE: Electronic Xross culture, Hypertexual Academy of Non-native Gatherings in English. Manao, HI.University of Hawaii press.

[18] Thanasoulas, D. (2000). Autonomy and Learning: An Epistemological Approach. Applied Semiotics Journal, Volume 4, Issue 10. University of Toronto, Canada, pp. 115-132

[19] Wang, J. (2010). How to Develop College Students' Autonomous English Learning Skills. Journal of Canadian Center of Science and Education, Volume 3, No. 3, September 2010.http://www.ccsenet.org/elt.

[20] Zhao, Y. Li, R. C. \& Hegelheimer, V. (1995). EX*CHANGE. http://deil.lang.uiuc.edu/exchange/.

[21] Zhong, Y. (2008). A Study of Autonomy English Learning on the Internet. Journal of Canadian Center of Science and Education (ELT Journal), Vol. 1, No. 2, 147-150.

Mohammad Nurul Islam (Ph.D.) was born in Bangladesh in 1975. He is an assistant professor in English, currently working in the Department of English, Faculty of Languages and Translations, King Khalid University, Kingdom of Saudi Arabia.

He has been teaching ELT and ESP at tertiary students' since a decade. His areas of interest include ELT, ESP and Language Testing etc. 